\title{
Reservoir Characteristics of the Lower Silurian Longmaxi Shale in Zhaotong Region, Southern China
}

\author{
Chao Luo $\mathbb{D}^{1}{ }^{1}$ Nanxin Yin, ${ }^{1}$ Hun Lin, ${ }^{1}$ Xuanbo Gao, ${ }^{1}$ Junlei Wang, ${ }^{2}$ and Hanqing Zhu $^{2}$ \\ ${ }^{1}$ Chongqing University of Science \& Technology, Chongqing 401331, China \\ ${ }^{2}$ Research Institute of Petroleum Exploration and Development, CNPC, Beijing 100083, China \\ Correspondence should be addressed to Chao Luo; lc_121989@163.com
}

Received 8 July 2020; Revised 24 July 2020; Accepted 31 July 2020; Published 25 August 2020

Academic Editor: Wei Yu

Copyright ( 92020 Chao Luo et al. This is an open access article distributed under the Creative Commons Attribution License, which permits unrestricted use, distribution, and reproduction in any medium, provided the original work is properly cited.

\begin{abstract}
The lower Silurian Longmaxi Formation hosts a highly productive shale gas play in the Zhaotong region of southern China. According to core observation, X-ray diffraction analyses, and scanning electron microscopy (SEM) observations, the shale comprises primarily quartz, carbonate minerals, and clay minerals, with minor amounts of plagioclase, K-feldspar, and pyrite. The clay mineral content ranges from $15.0 \%$ to $46.1 \%$, with an average of $29.3 \%$ in the Zhaotong region. Organic geochemical analyses show that the Longmaxi Formation has good potential for shale gas resources by calculating total organic carbon, vitrinite reflectance, and gas content. Scanning electron microscope images demonstrate that reservoir pore types in the Longmaxi shale include organic pores, interparticle pores, intercrystalline pores, intraparticle pores, and fractures. Reservoir distribution is controlled by lithofacies, mineral composition, and geochemical factors. In addition, we investigated the relationships between reservoir parameters and production from 15 individual wells in the Zhaotong region by correlation coefficients. As a result, the brittleness index, total organic carbon (TOC), porosity, and gas content were used to define high-quality reservoirs in the Longmaxi shale. Based on these criteria, we mapped the thickness and distribution of high-quality reservoirs in the Longmaxi Formation and selected highlighted several key sites for future exploration and development.
\end{abstract}

\section{Introduction}

Shale gas is one of the main forms of unconventional natural gas. It occurs within certain organic-rich shale and is generally present in an adsorbed or free state [1-4]. China was the third country to commercially develop shale gas, after the United States and Canada [5-7]. The Changning, Weiyuan, Zhaotong, and Fuling marine shale gas demonstration zones achieved a combined annual output of $79 \times 10^{8} \mathrm{~m}^{3}$ in 2017 [8]. China has great potential for additional shale gas exploration, and the production of shale gas in the country is forecast to reach $800-1000 \times 10^{8} \mathrm{~m}^{3}$ by 2030 [9].

Despite their production potential, shale gas reservoirs are often highly heterogeneous $[10,11]$ and have poor petrophysical properties [12-14]. Parameters such as shale thermal maturity, organic matter content, net thickness, burial depth, recoverable area, gas content, and Young's modulus are used to describe shale gas reservoirs [15]. Hashmy et al. define high-quality unconventional gas reservoirs as having petrophysical properties that are conducive to good flow [16]. Zou et al. proposed criteria for evaluating unconventional gas reservoirs, including depositional environment, thermal evolution, pore and fracture development, and tectonic preservation condition [17]. Successful shale gas development is dependent on the discovery of high-quality reservoirs [18].

The shale gas well has low natural productivity in Longmaxi Formation, so it needs fracturing transformation to obtain higher production. Evaluation of high-quality reservoirs is the key to shale gas development in this area. The previous evaluation system analyzes the characteristics of high-quality reservoirs from the perspectives of shale rock [19], mineral [20], physical property [21], gas bearing [22], geochemistry [23], and resource potential [24], but the relationship between reservoir parameters and gas well production is rarely discussed. In this paper, we characterized the Longmaxi Formation's shale gas reservoirs in the Zhaotong region of the Sichuan Basin, southern China, by 
core observation, X-ray diffraction analyses, and scanning electron microscopy (SEM) observations. As a result, we quantified the reservoir properties of Longmaxi Formation and selected the best parameters for shale gas reservoir evaluation. Our results provide a theoretical framework to support future shale gas exploration and development in southern China and similar regions elsewhere.

\section{Regional Geological Setting}

The Sichuan Basin, in southwestern China, contains petroliferous deposits that can be found over an area of approximately $26 \times 10^{4} \mathrm{~km}^{2}$. The Sichuan Basin is bounded by the Longmenshan Fault to the west, the Chengkou-Fangxian and Xiangguang faults to the north, and the Shizong-Mile and Danchi-Du'an faults to the south (Figure 1). The Zhaotong region lies to the south of the Chuannan fold belt in the southern Sichuan Basin [25].

Southern China experienced intense tectonic compression in the Late Ordovician-Early Silurian [26]. As the Paleo-Tethys Ocean subducted during the Early-Middle Ordovician, the northern Yangtze Cratonic Basin shrank [27]. Moderate bathymetric uplift drove a transition from marine to restricted marine conditions at this time [28]. In the Sichuan Basin's hypoxic deep-water shelf environment, the moderately uplifted bathymetry, low-energy conditions, and low-sedimentation rate allowed for the accumulation of thick, widespread marine shale. This marine shale sequence includes the black graptolitic shale of the Longmaxi Formation [29]. Gamma values in the Sichuan Basin shale sequence peak in the Wufeng Formation (at the Ordovician-Silurian transition), before gradually decreasing upward. The Longmaxi shale is an important source rock in the Sichuan Basin $[30,31]$, where it is widespread and $55-516 \mathrm{~m}$ in thickness. The Longmaxi shale is divided into two parts from bottom to top: the lower part is rich in organic matter and graptolites, and is the main gas-producing layer; the upper part is a thick succession of silty shale, which formed in a shallow-water sandy shelf environment.

\section{Database and Methodology}

This study utilized $221.98 \mathrm{~m}$ of 3 cores, 132 slices of core, $\mathrm{X}$-ray diffraction data from 52 samples, source rock data from 91 samples (vitrinite reflectance, TOC, and macerals), scanning electron microscopy (SEM) observations from 72 samples, and porosity-permeability measurements from 32 samples.

Powdered shale samples were analyzed for TOC content using a LECO CS-230 carbon-sulfur analyzer at $25^{\circ} \mathrm{C}$ and $30 \%$ humidity. Vitrinite reflectance $\left(R_{o}\right)$ was measured using a Zeiss mpv-sp microphotometer. An X'Pert Pro X-ray diffractometer was used to determine the mineralogical compositions and clay fractions. These three tests were conducted at the State Key Laboratory of Oil and Gas Reservoir Geology and Exploration at the Southwest Petroleum University in Chengdu, China.

Twelve samples were selected to investigate the shale pore types and morphologies. The analyses were conducted using a FEI Quanta 200F field emission scanning electron microscope (FE-SEM) at the State Key Laboratory of Petroleum Resources and Prospecting at the China University of Petroleum in Beijing. The samples were treated with an argon ion profile and an ion sputtering coating. Imaging was carried out at $24^{\circ} \mathrm{C}$ and $35 \%$ humidity. The scanning electron microscope was used to determine the microscopic pore structure characteristics (morphology, types, and distribution) of the shale samples [32].

A nitrogen adsorption experiment was carried out at $-196^{\circ} \mathrm{C}$ using a Quadrasorb SI specific surface analyzer. Before the experiment, samples were degassed for 20 hours under vacuum at a temperature of $110^{\circ} \mathrm{C}$.

\section{Results}

4.1. Mineralogy. X-ray diffraction analyses show that the shale mineralogies include quartz, feldspar, calcite, dolomite, pyrite, and clay. Quartz is the most abundant mineral, with an average content of $30.50 \%$. The average contents of calcite and dolomite are $17.24 \%$ and $14.12 \%$, respectively. The clay mineral content ranges from $15.0 \%$ to $46.1 \%$, with an average of $29.3 \%$. The clay mineral compositions include mainly illite (49\%-73\%, with an average of $54.0 \%)$ and chlorite $(8 \%-28 \%$, with an average of $15.4 \%)$, followed by illite/montmorillonite $(12 \%-41 \%$, with an average of $28.8 \%)$ (Table 1$)$. The brittleness index is the sum of the quartz and feldspar contents. The brittleness index of sample ZT1-4 is the highest (0.499), and the brittleness index of sample ZT1-2 is the lowest (0.139).

4.2. Lithology. The Longmaxi Formation is approximately 50-200 $\mathrm{m}$ thick in the Zhaotong region. Six main lithofacies were identified from the $221.98 \mathrm{~m}$ Longmaxi Formation core: siliceous shale, carbonaceous shale, calcareous shale, silty shale, gray mudstone, and muddy siltstone (Figure 2).

The siliceous shale from the Longmaxi core is laminated and dark in color. A high content of cryptocrystalline silica makes this facies very hard overall, and the covering area of graptolite content is generally $<30 \%$. The carbonaceous shale is foliated with a large amount of carbonized organic matter and a high TOC content. The most abundant minerals are quartz, clays, feldspar, pyrite, and calcite. The calcareous shale has well-developed horizontal bedding and a high calcite content. The graptolite coverage area is generally $<10 \%$. The silty shale contains dark, organic-rich clay and lighter particles of quartz, feldspar, and other detritus. Detrital particles account for $25 \%-45 \%$ of the total mineralogy. The gray mudstone has a light gray color and is composed of clay minerals with fine silt. The muddy siltstone contains clastic particles of quartz and feldspar, with horizontal to wavy bedding.

The siliceous and carbonaceous shales formed in a reducing, deep-water environment. These lithofacies are found in the lower part of the Longmaxi Formation, where the deepwater shelf environment was conducive to the deposition of source rocks. The TOC content of these lithofacies is $>2 \%$, which is favorable for shale gas. Calcareous shale, silty shale, gray mudstone, and argillaceous siltstone mainly occur in the upper part of the Longmaxi Formation. The upper part of the formation was deposited in a shallow shelf environment, and 


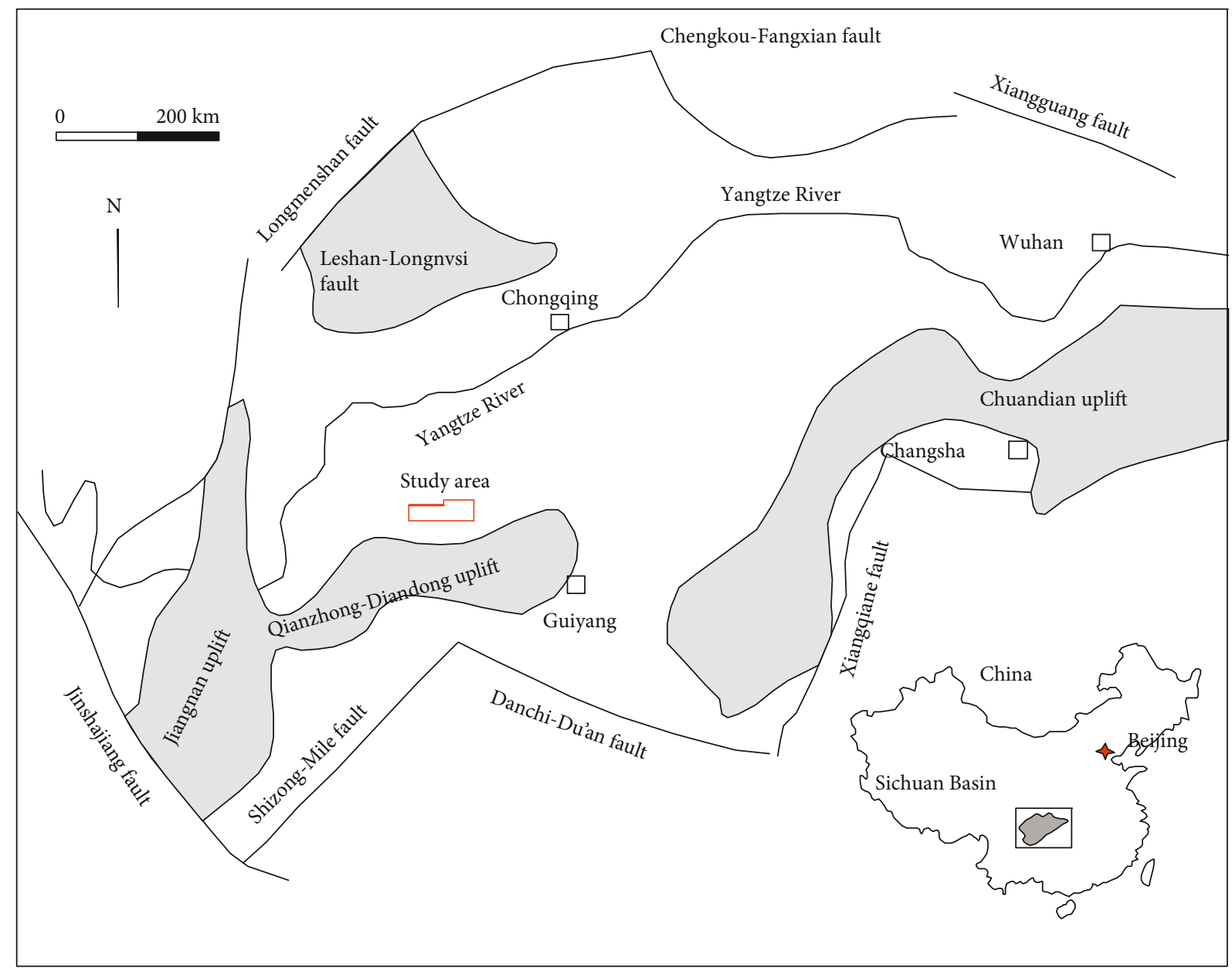

(a)

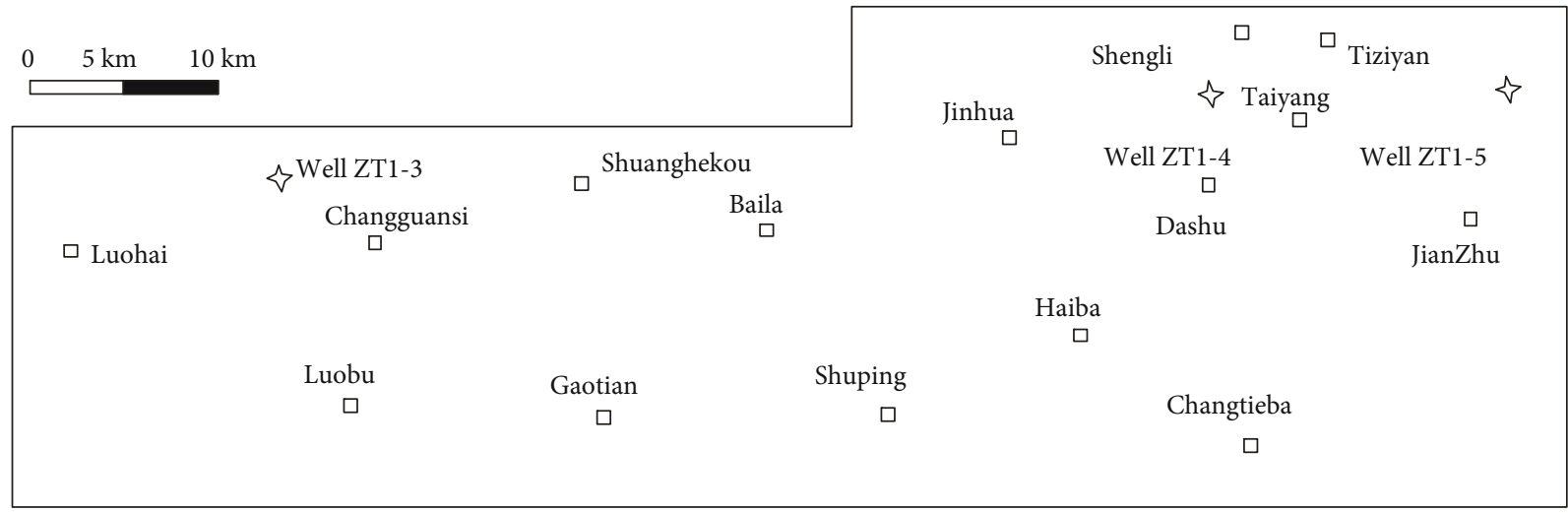

(b)

Figure 1: Continued. 


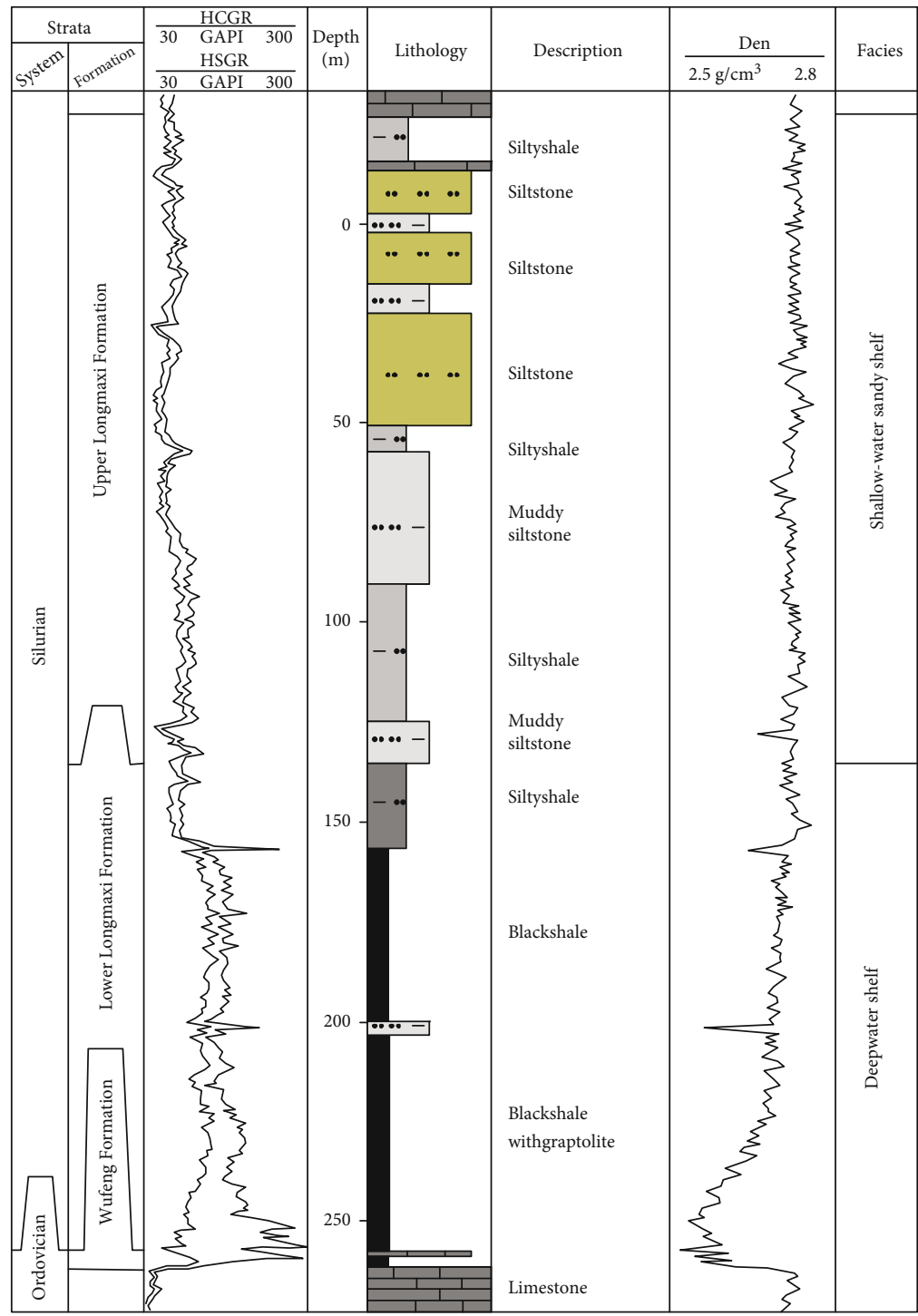

(c)

FIgure 1: (a) Structural sketch map of the Sichuan Basin, southern China. The position of (b) is marked in red; (b) the study area with towns (squares) and well locations (diamonds); (c) summary diagram showing the stratigraphy and basin evolution of the Sichuan Basin (modified from Liang et al., 2014).

it records the gradual transition from anoxic, reducing conditions to oxygen-rich, oxidizing conditions. Preservation potential for organic matter was poor, so the organic carbon content of these deposits is $<2 \%$.

\subsection{Organic Geochemical Characteristics}

4.3.1. TOC. The TOC content of the Longmaxi shale reaches a maximum of $4.79 \mathrm{wt} . \%$, with an average of $2.76 \mathrm{wt} . \%$. The TOC content varies according to lithofacies, with siliceous shale and carbonaceous shale having the highest TOC contents. There is also a gradual upward-decreasing trend in TOC content in the lower part of the Longmaxi shale.

4.3.2. Thermal Maturity. Vitrinite reflectance $\left(R_{o}\right)$ values for the Longmaxi shale are between $1.95 \%$ and $3.13 \%$, with an average of $2.48 \%$. The $R_{o}$ values indicate that the source rock is highly mature and that it has reached the hot gas window.

4.3.3. Gas Content. Core analyses indicate that the adsorbed gas content of Longmaxi shale is $1.6-2.1 \mathrm{~m}^{3} \mathrm{t}^{-1}$. Previous studies have shown that the adsorbed gas content of shale is positively correlated with TOC content [33]. This is due to the strong adsorption potential of gas on organic compounds [34]. In shales, large amounts of gas can be adsorbed on the surface of kerogen, so high TOC contents can indicate large gas volumes and high adsorption capacity for shale gas. Shale gas content is also affected by mineral composition, porosity, and other factors [35].

4.4. Reservoir Storage Space. Pores form the main reservoir space in shales. Scanning electron microscope images reveal 
TABLE 1: Mineralogy of shale samples from the Zhaotong region.

\begin{tabular}{|c|c|c|c|c|c|c|c|c|c|c|c|c|c|}
\hline \multirow[t]{2}{*}{ Sample ID } & \multirow{2}{*}{ TOC (\%) } & \multirow{2}{*}{$R_{o}(\%)$} & \multicolumn{7}{|c|}{ Mineral content (\%) } & \multicolumn{4}{|c|}{$\begin{array}{c}\text { Relative content of } \\
\text { clay }(\%)\end{array}$} \\
\hline & & & Quartz & K-feldspar & Plagioclase & Calcite & Dolomite & Pyrite & Clay & $\mathrm{I} / \mathrm{S}$ & $\mathrm{I}$ & $\mathrm{K}$ & $\mathrm{C}$ \\
\hline ZT1-1 & 2.15 & 2.46 & 12.1 & 0.8 & 1.6 & 29.3 & 21.2 & 1.7 & 33.3 & 12 & 73 & 2 & 13 \\
\hline ZT1-2 & 2.56 & 2.64 & 11.5 & 0.7 & 1.7 & 19.8 & 15.4 & 4.8 & 46.1 & 22 & 64 & 2 & 12 \\
\hline ZT1-3 & 3.31 & 2.47 & 37.2 & 0.6 & 4.9 & 19 & 17.4 & 2.4 & 18.5 & 41 & 49 & 1 & 9 \\
\hline ZT1-4 & 4.15 & 2.51 & 48.3 & 0.8 & 0.8 & 8.7 & 15.6 & 3.5 & 22.3 & 41 & 50 & 1 & 8 \\
\hline ZT1-5 & 4.79 & 2.59 & 28.9 & 0.9 & 4 & 13 & 15.8 & 6 & 31.4 & 28 & 58 & 2 & 12 \\
\hline ZT1-6 & 2.31 & 1.95 & 37.9 & 1.1 & 9.5 & 7.4 & 4.8 & 4 & 35.3 & 26 & 51 & 2 & 21 \\
\hline ZT1-7 & 3.13 & 2.02 & 29.3 & 1.6 & 4.2 & 9.9 & 5.9 & 3.2 & 45.9 & 23 & 52 & 2 & 23 \\
\hline ZT1-8 & 1.17 & 2.42 & 34.2 & 1.3 & 8.1 & 12.3 & 4.5 & 1.3 & 38.3 & 26 & 51 & 2 & 21 \\
\hline ZT1-9 & 1.88 & 2.49 & 30.4 & 3.1 & 9.3 & 16.6 & 5 & 3.1 & 32.5 & 18 & 54 & 2 & 26 \\
\hline ZT1-10 & 0.91 & 2.35 & 37.9 & 4.6 & 6.5 & 12 & 3.9 & 0.6 & 34.5 & 20 & 50 & 2 & 28 \\
\hline ZT1-11 & 3.35 & 3.13 & 17.9 & 0.9 & 2.3 & 36.5 & 23.1 & 2.7 & 16.6 & 32 & 53 & 2 & 13 \\
\hline ZT1-12 & 0.86 & 2.41 & 24.3 & 0.9 & 6.1 & 31.4 & 21.5 & 0.8 & 15 & 32 & 52 & 2 & 14 \\
\hline ZT1-13 & 3.17 & 2.59 & 41.8 & 0.8 & 4.6 & 16.4 & 14.9 & 2 & 19.5 & 37 & 52 & 1 & 10 \\
\hline ZT1-14 & 3.47 & 2.43 & 35.1 & 0.7 & 5.5 & 13.7 & 20.1 & 2.2 & 22.7 & 38 & 50 & 2 & 10 \\
\hline ZT1-15 & 4.16 & 2.67 & 30.7 & 1.1 & 1.2 & 12.6 & 22.7 & 4.4 & 27.3 & 36 & 51 & 2 & 11 \\
\hline
\end{tabular}

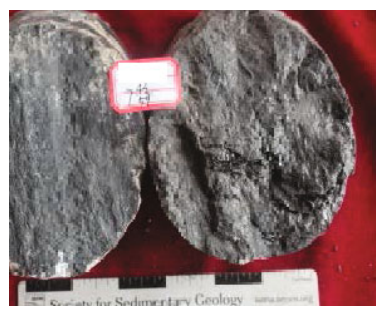

(a)

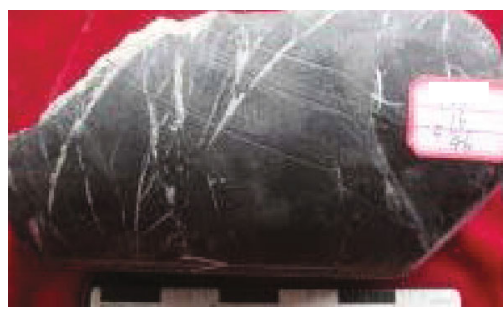

(c)

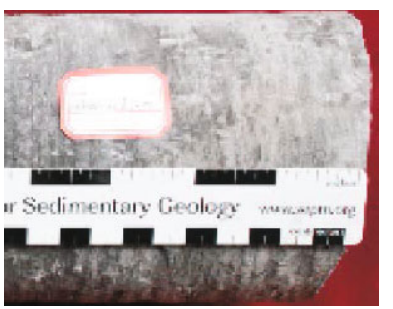

(e)

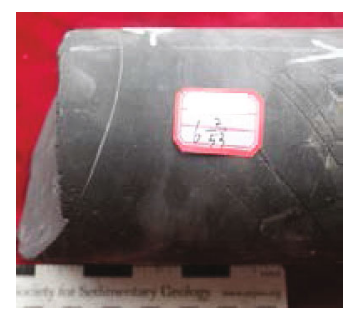

(b)

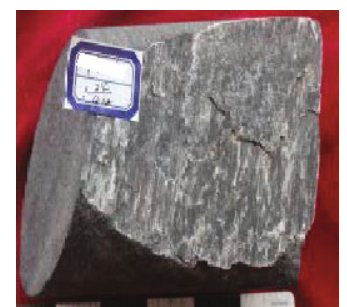

(d)

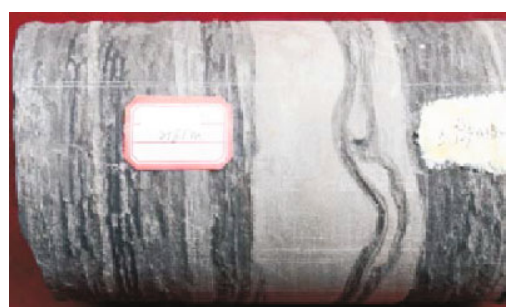

(f)

FIGURE 2: Shale facies of the Longmaxi Formation in the Zhaotong region: (a) carbonaceous shale; (b) siliceous shale, dark in color and hard, with a high $\mathrm{SiO}_{2}$ content; (c) calcareous shale, contains high angle fractures that are filled with calcite; (d) silty shale, light layers contain mainly quartz and feldspar, while the dark layers contain high clay and organic matter contents; (e) gray mudstone, light gray in color; (f) muddy siltstone, displays wavy to horizontal bedding. 


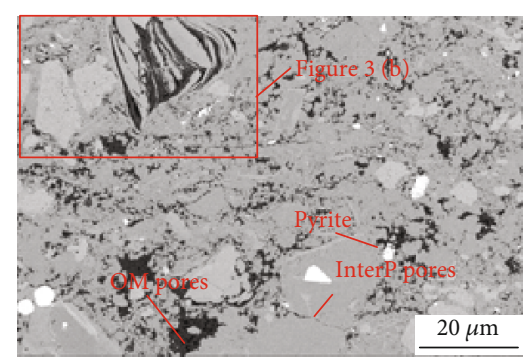

(a)

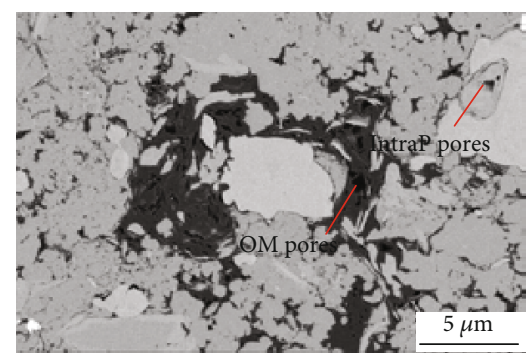

(c)

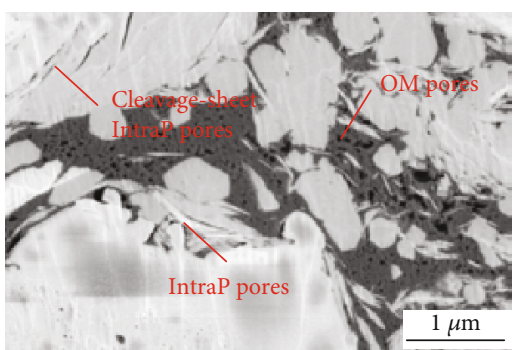

(e)

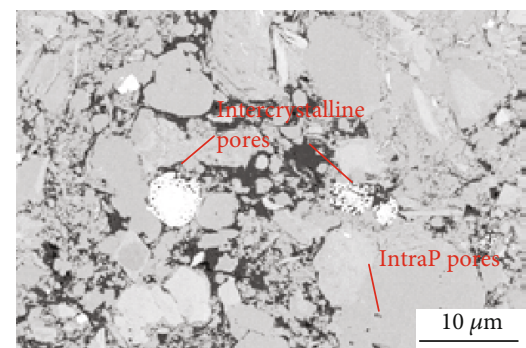

(g)

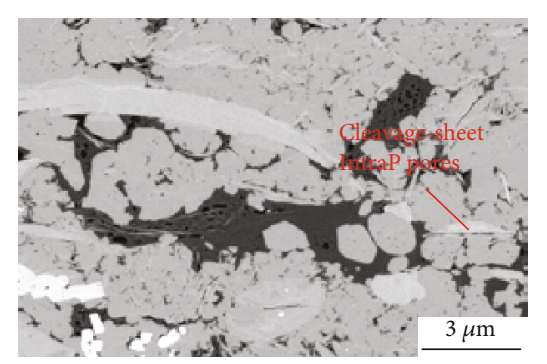

(i)

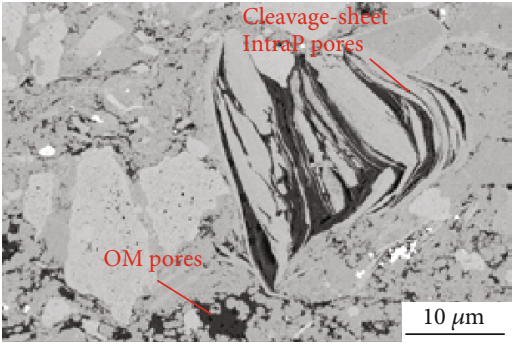

(b)

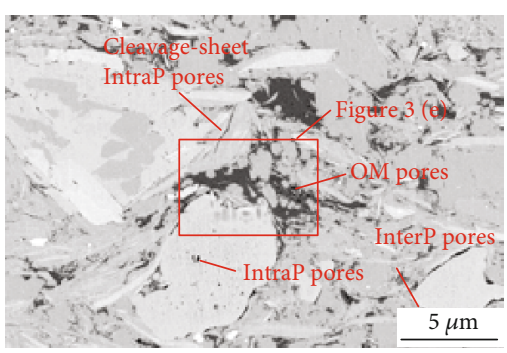

(d)

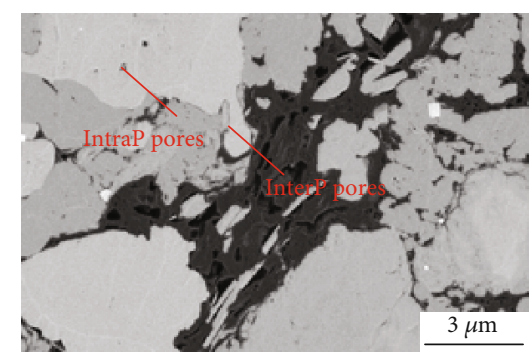

(f)

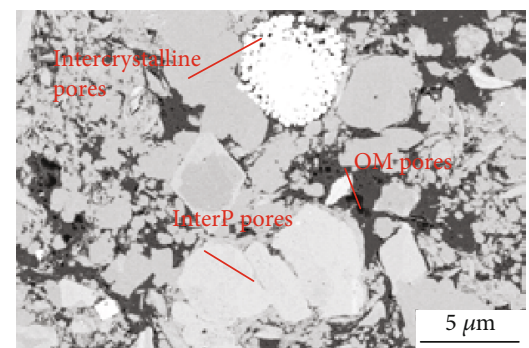

(h)

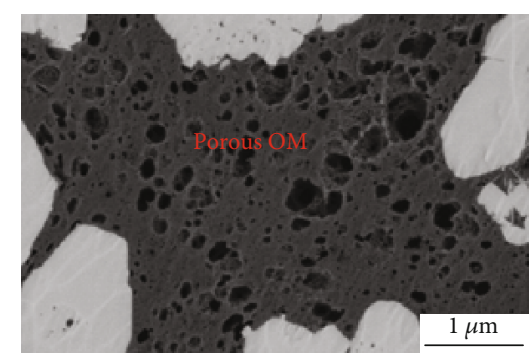

(j)

Figure 3: Continued. 


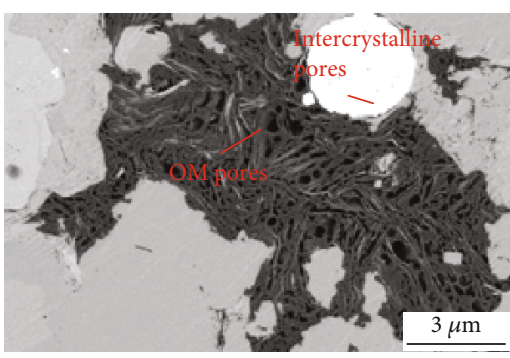

(k)

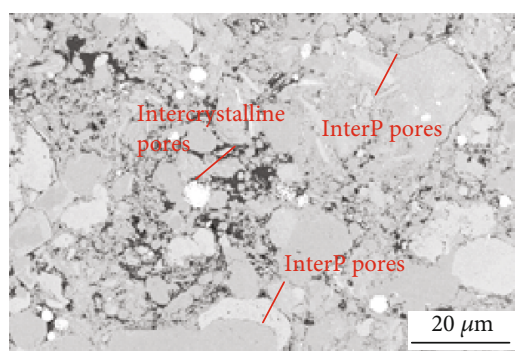

(l)

FIGURE 3: FE-SEM images of shale samples from the Zhaotong region. (a) Organic matter (OM) pores, pyrites, and interP pores at the edges of mineral grains (b) OM pores and cleavage-sheet intraP pores in clay particles; (c) OM pores and fluid-inclusion intrapores; (d) OM pores in $\mathrm{OM}$ grains, cleavage-sheet intrapores in clay particles, intrapores with calcite grains, and interpores at the edges of mineral grains; (e) OM pores, cleavage-sheet intrapores within clay particles, and interpores at the edges of mineral grains; (f) fluid-inclusion intrapores within brittle minerals and interpores at the edge of a calcite grain; (g) fluid-inclusion intrapores within brittle minerals and intercrystalline interpores in pyrite framboids; (h) OM pores, intercrystalline pores in pyrite framboids, and interpores at the edges of mineral grains; (i) cleavage-sheet intrapores within clay particles; (j) large OM particle with irregular and elliptical OM pores; (k) OM particle and intercrystalline interpores in pyrite framboids; (l) intercrystalline interpores in pyrite framboids and interpores at the edges of mineral grains.

several pore types in the Longmaxi shale samples, including organic pores, intercrystalline pores, intraparticle (intraP) pores, and interparticle (interP) pores (Figure 3). The organic pores are widely developed in the shale and formed during the later stages of thermal evolution. When source rocks reach the threshold for hydrocarbon generation, pores form in the organic matter as hydrocarbons are produced and expelled. The organic pores generally have laminar, pitted, ellipsoidal, polygonal, and irregular shapes. Organic pore sizes are highly variable in the Longmaxi shale, ranging from 10 to $1500 \mathrm{~nm}$. These pore sizes are medium-large and can develop within both nanoscale and microscale organic matter (Figures 3(a) and 3(j)). Interparticle pores and intraparticle dissolved pores are both considered intergranular pores and mainly formed via late diagenetic processes, though there are a few primary interparticle pores (Figures 3(b), 3(d), 3(e), and 3(i)). Pyrite intercrystalline pores are widely developed in the shale [36]. When pyrite aggregates are partially dissolved, the resulting pores are filled with organic matter and newer pyrite crystals [37-42]. The organic matter in the Longmaxi shale is often coated with pyrite particles. Calcite and dolomite intraparticle dissolved pores are relatively small and rare (Figures 3(c) and 3(f)) in the Longmaxi shale. The dissolved pores appear to be complete, and there is no evidence of extrusion deformation, which indicates that they formed during burial.

4.5. Reservoir Properties. The Longmaxi shale has porosities between $0.83 \%$ and $6.70 \%$, with an average of $4.70 \%$. The permeability is very low, ranging from 0.0028 to $0.0417 \mu \mathrm{D}$, with an average of $0.0176 \mu \mathrm{D}$. The specific surface area is between 1.72 and $29.31 \mathrm{~m}^{2} \mathrm{~g}^{-1}$, with an average value of $9.88 \mathrm{~m}^{2} \mathrm{~g}^{-1}$. The throat radius values range from 3.0 to $19.8 \mathrm{~nm}$, with an average of $7.5 \mathrm{~nm}$. The total pore volumes of the Longmaxi shale range from 49 to $388 \times 10^{-4} \mathrm{ml} \mathrm{g}^{-1}$, with an average of $123 \times 10^{-4} \mathrm{ml} \mathrm{g}^{-1}$. The volumes of the pores $(<2 \mathrm{~nm})$ range from 15.2 to $37.4 \times 10^{-4} \mathrm{mlg}^{-1}$, with an average of $5.8 \times 10^{-4} \mathrm{ml} \mathrm{g}^{-1}$. Mesopore volumes are distributed between 41.4 and $287.0 \times 10^{-4} \mathrm{mlg}^{-1}$, with an average of $110.0 \times 10^{-4}$ $\mathrm{mlg}^{-1}$. Micropores, mesopores, and macropores $(>50 \mathrm{~nm})$ constitute $4.70 \%, 89.43 \%$, and $5.87 \%$ of the total pore volume, respectively, indicating that mesopores are dominant in the Longmaxi shale.

\section{Discussion}

5.1. Selection of Parameters for Reservoir Evaluation. We used well data from the Zhaotong region to investigate the relationships between reservoir parameters and gas production from the Longmaxi Formation. We used open-flow productivity data from 15 wells, which had each been fractured by similar amounts prior to measurement. Reservoir parameters have different effects on gas production from shale, and these effects can be determined using correlation coefficients.

We used correlation coefficients to determine the importance and effect of each input and output index. We let the input index terms be $X_{1}, X_{2}, \cdots, X_{m}$. The greater the correlation coefficient between the input index $X_{i}$ and the output index, the stronger the relationship between $X_{i}$ and the output index. The correlation coefficient $R_{i}$ is defined as

$$
R_{i}=\frac{\operatorname{Cov}(X, Y)}{\sqrt{D(X)} \sqrt{D(Y)}} .
$$

Mud, silica, calcium, organic matter, and kerogen contents, thermal maturity, total porosity, gas saturation, and pore pressure gradient were selected as input indices, and gas production was used as the output index. The parameters that were used to evaluate reservoir properties were selected using the correlation coefficient $R_{i}$. The controlling geological parameters will vary between different shale gas reservoirs.

We used logged cores from the Zhaotong region to extract parameters such as mud content, brittleness index, silica content, calcium content, TOC, kerogen content, total porosity, gas saturation, pore pressure gradient, and $R_{o}$. The total gas content is expressed as the actual gas production after fracturing. By studying the correlation coefficients between these 


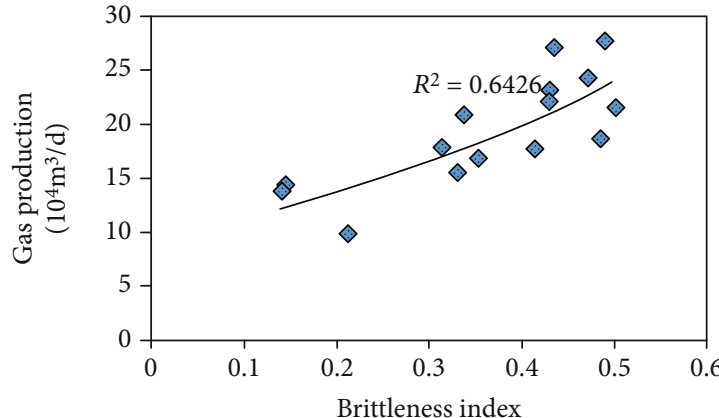

(a)

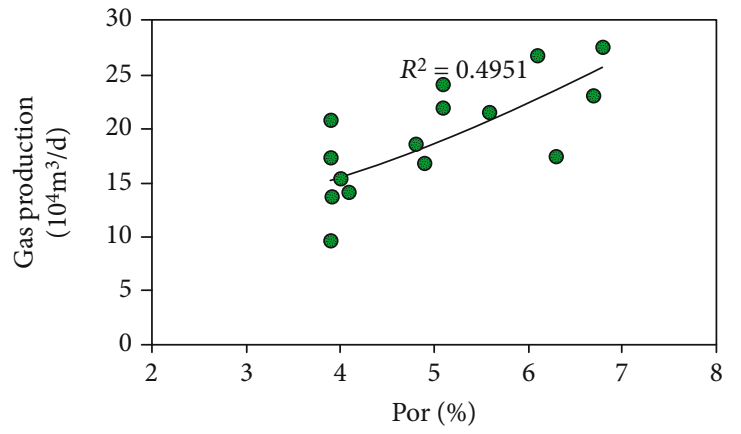

(c)

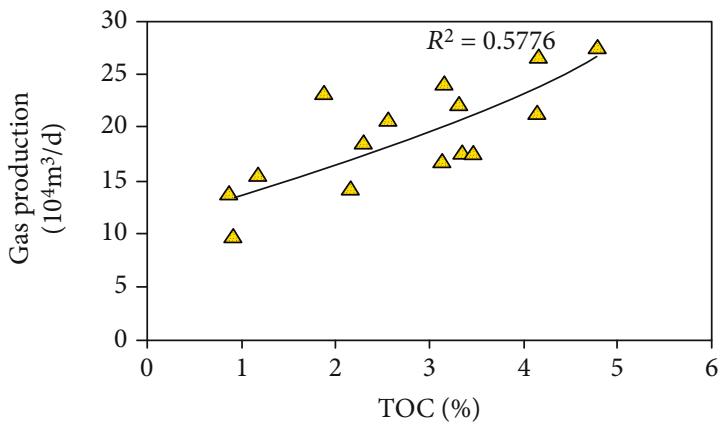

(b)

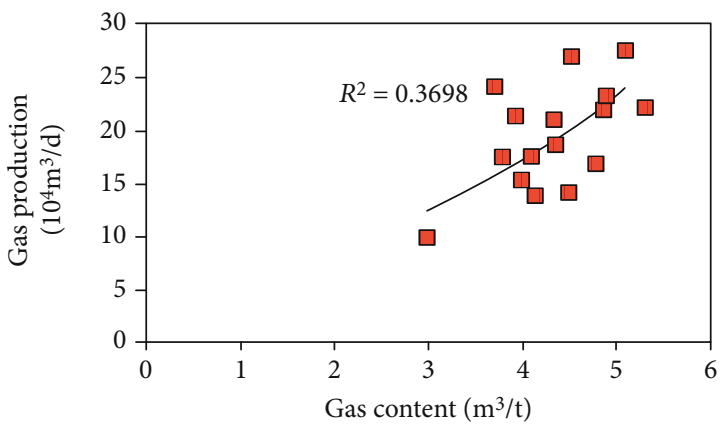

(d)

FIGURE 4: Longmaxi shale gas reservoir parameters and gas production in the Zhaotong region: (a) brittleness index; (b) TOC; (c) porosity; (d) gas content.

reservoir parameters and gas production, we found that the brittleness index, TOC, porosity, and gas content have the strongest influence on gas production, with correlation coefficients $>0.35$, while $R_{o}$, pore pressure gradient, argillaceous content, siliceous content, and calcium content have little effect on gas production, with correlation coefficients $<0.35$.

By analyzing shale gas reservoir parameters in the Zhaotong area, we determined that the brittleness index, TOC, porosity, and gas content are the most influential parameters for gas production (and therefore reservoir quality). The highest observed correlation coefficients were between brittleness index and gas production (0.6426), followed by TOC and gas production (0.5776); correlation coefficients between porosity and gas production (0.4951) and gas content and gas production (0.3698) were lower. The correlation coefficients reveal that the most influential parameters on gas production are brittleness index $>\mathrm{TOC}>$ porosity>gas content (Figure 4).

5.2. High-Quality Reservoir Definition and Distribution. The evaluation criteria for shale reservoirs in the Zhaotong region include TOC, gas content, porosity, and brittle mineral index. We have shown that these are the four key parameters that influence shale gas production. To be considered high-quality, reservoirs in the Longmaxi Formation should meet the following criteria: TOC $>4 \%$, gas content $>4 \mathrm{~m}^{3} \mathrm{t}^{-1}$, porosity $>5 \%$, and brittleness index $>0.45$ (Table 2).

The shale in the upper part of Longmaxi Formation was deposited on a shallow-water sandy shelf. Shale deposition in this environment was discontinuous, and it is therefore
TABLE 2: Identification criteria for high-quality reservoirs in the Zhaotong region.

\begin{tabular}{lc}
\hline Key parameters & Criteria \\
\hline TOC & $>4 \%$ \\
Gas content & $>4 \mathrm{~m}^{3} \mathrm{t}^{-1}$ \\
Porosity & $>5 \%$ \\
Brittleness index & $>0.45$ \\
\hline
\end{tabular}

unlikely that the shale forms effective reservoirs for industrial exploitation. We mapped the thickness of high-quality reservoirs in the lower Longmaxi Formation using the identification criteria described above. Our results show that the next phase of shale gas exploration and development should focus on the northern and central parts of the study area (Figure 5).

\section{Conclusions}

In this study, reservoir characteristics of the lower Silurian Longmaxi shale were analyzed in the Zhaotong region, southern China. Some important findings are summarized as follows:

(1) The Longmaxi shale contains six main lithofacies: siliceous shale, carbonaceous shale, calcareous shale, silty shale, gray mudstone, and muddy siltstone. The concentration of brittle minerals is high, which is conducive to the formation of natural and artificial fractures 


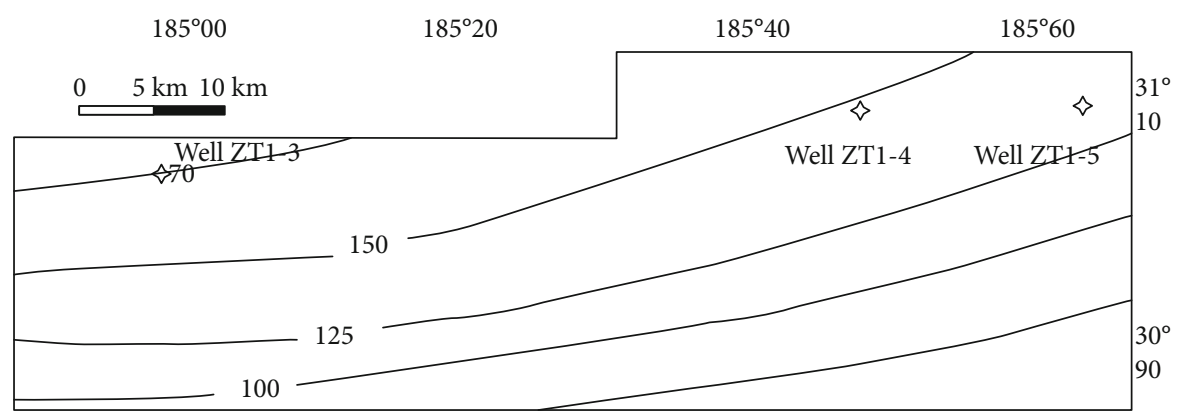

(a)

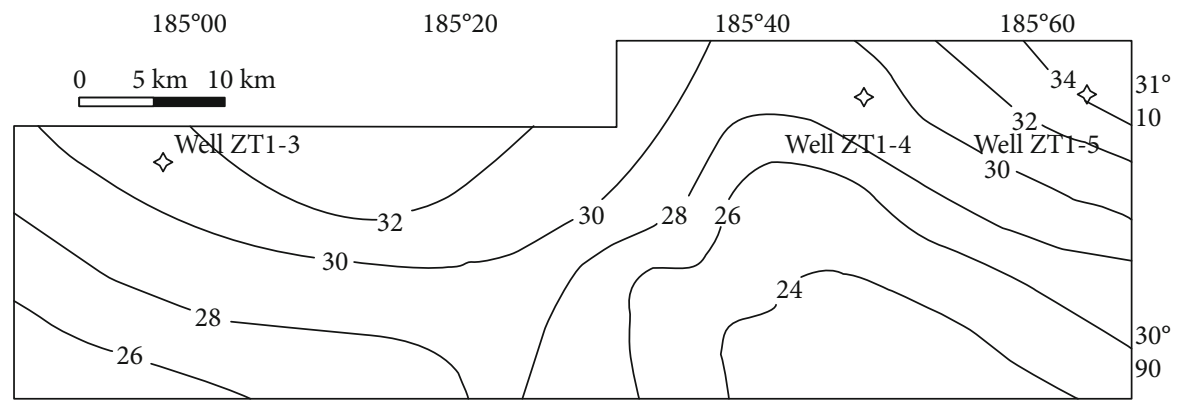

(b)

FIGURE 5: Isopach maps for the Zhaotong region: (a) the Longmaxi Formation thickness; (b) high-quality shale gas reservoir thickness in the Longmaxi Formation.

(2) Geochemical analyses (TOC, $R_{o}$, and gas content) show that the Longmaxi shale has good potential for shale gas resources. The primary reservoir space consists of organic pores, intercrystalline pores, intraparticle pores, and interparticle pores. Most of the pores are $2-50 \mathrm{~nm}$ in size (mesopores). Open-flow production data were used to investigate the relationships between various reservoir index parameters and gas production from the Longmaxi Formation

(3) Data from fifteen wells in the Zhaotong region were used, and each had experienced a similar amount of fracturing. The results show that TOC, gas content, porosity, and brittleness index are the most influential parameters for shale gas production from the Longmaxi Formation. We propose that high-quality Longmaxi shale gas reservoirs in the Zhaotong region should be defined using the following criteria: TOC $>4 \%$, gas content $>4 \mathrm{~m}^{3} \mathrm{t}^{-1}$, porosity $>4 \%$, and brittleness index $>0.45$

(4) Our mapping of the high-quality Longmaxi shale gas reservoirs in the Zhaotong region indicates that the next phase of exploration and development should focus on the northern and central parts of the study area

\section{Abbreviations}

$$
\begin{aligned}
& X_{i}: \\
& m: \\
& R_{i}:
\end{aligned}
$$

Input index

Number of parameters

Correlation coefficient of single factor
Covariance of $\operatorname{cov}(x, y): x$ and $y$

Variance of $D(x): \quad x$

Variance of $D(y): \quad y$

$R_{o}: \quad$ Vitrinite reflectance

$R^{2}: \quad$ Correlation coefficient.

\section{Data Availability}

The data used to support the findings of this study are available from the corresponding author upon request.

\section{Disclosure}

The findings achieved herein are solely the responsibility of the authors.

\section{Conflicts of Interest}

The authors declare that they have no conflicts of interest.

\section{Acknowledgments}

This study was financially supported by the National Science Technology Major Project (No. 2016ZX05015), PetroChina Innovation Foundation (No. 2019D-5007-0210), National Natural Science Foundation of China (Grant No.51904050), Chongqing Natural Science Foundation Project (Nos. cstc2019jcyj-msxmX0725 and cstc2019jcyjmsxmX045), and Science and Technology Research Program of Chongqing Municipal Education Commission (Grant No. KJQN201901531). 


\section{References}

[1] R. Ariketi, U. K. Bhui, S. Chandra, and S. Biswal, "Brittleness modeling of Cambay shale formation for shale gas exploration: a study from Ankleshwar area, Cambay Basin, India," Journal of Petroleum Exploration and Production Technology, vol. 7, no. 4, pp. 326-923, 2017.

[2] V. Rasouli, "Geomechanics of gas shales," in Fundamentals of Gas Shale Reservoirs, R. Rezaee, Ed., pp. 169-190, John Wiley \& Sons, Inc., Hoboken, NJ, USA, 2015.

[3] R. D. Vidic, S. L. Brantley, J. M. Vandenbossche, D. Yoxtheimer, and J. D. Abad, "Impact of shale gas development on regional water quality," Science, vol. 340, no. 6134, article 1235009, 2013.

[4] Y. Guo, L. Wang, X. Chang, J. Zhou, and X. Zhang, "Study on fracture morphological characteristics of refracturing for longmaxi shale formation," Geofluids, vol. 2020, Article ID 1628431, 13 pages, 2020.

[5] C. Jia, M. Zheng, and Y. Zhang, "Unconventional hydrocarbon resources in China and the prospect of exploration and development," Petroleum Exploration and Development, vol. 39, no. 2, pp. 139-146, 2012.

[6] D. J. K. Ross and R. M. Bustin, "Investigating the use of sedimentary geochemical proxies for paleoenvironment interpretation of thermally mature organic-rich strata: Examples from the Devonian-Mississippian shales, Western Canadian Sedimentary Basin," Chemical Geology, vol. 260, no. 1-2, pp. 1-19, 2009.

[7] P. Wang, C. Zou, X. Li et al., "Main geological controlling factors of shale gas enrichment and high yield in Zhaotong demonstration area," Acta Petrolei Sinica, vol. 39, no. 7, pp. 744-753, 2018.

[8] F. Shang, Y. Zhu, H. Gao, Y. Wang, and R. Liu, "Relationship between tectonism and composition and pore characteristics of shale reservoirs," Geofluids, vol. 2020, Article ID 9426586, 14 pages, 2020.

[9] X. Liang, Z. Xu, Z. Zhang et al., "Breakthrough of shallow shale gas exploration in Taiyang anticline area and its significance for resource development in Zhaotong, Yunnan province, China," Petroleum Exploration and Development, vol. 47, no. 1, pp. 12-29, 2020.

[10] J. Yang, J. Leng, L. Qiao, L. Wang, and J. Ding, "Parameter prediction of water imbibition in unsaturated shales using the NMR method," Geofluids, vol. 2019, Article ID 4254159, 9 pages, 2019.

[11] G. Wang, A. Jia, Y. Wei, and C. Xiao, "Transient pressure analysis for multifractured horizontal well with the use of multilinear flow model in shale gas reservoir," Geofluids, vol. 2020, Article ID 8348205, 20 pages, 2020.

[12] G. J. Prise, D. R. Stewart, and T. M. Bird, "Successful completion operations on Ravenspurn North development," in Offshore Europe, 7-10 September 1993, pp. 53-61, Aberdeen, UK, 1993.

[13] M. Qin, Z. Cao, J. Guo, Y. Huang, L. Sun, and L. Dong, "Characteristics of shale reservoir and sweet spot identification of the Lower Cambrian Niutitang Formation in Northwestern Hunan Province, China," Acta Geologica Sinica - English Edition, vol. 93, no. 3, pp. 573-587, 2019.

[14] S. Zhang, H. Liu, Y. Liu et al., "Main controls and geological sweet spot types in Paleogene shale oil rich areas of the Jiyang Depression, Bohai Bay basin, China," Marine and Petroleum Geology, vol. 111, pp. 576-587, 2020.
[15] L. Chorn, J. Yarus, S. del Rosario-Davis, and J. Pitcher, "Identification of shale sweet spots using key property estimates from log analysis and geostatistics," in Unconventional Resources Technology Conference, Denver, Colorado, 12-14 August 2013, pp. 1511-1523, USA, 2013.

[16] K. H. Hashmy, S. Abuelta, and C. Barnett, "Log-based identification of sweet spots for effective fracs in shale reservoirs," in Canadian Unconventional Resources Conference, 15-17 November 2011, pp. 1-11, Calgary, Canada, 2011.

[17] C. Zou, "Shale gas in China: characteristics, challenges and prospects," Petroleum Exploration \& Development, vol. 42, no. 6, pp. 689-701, 2015.

[18] W. B. Su, Z. M. Li, F. R. Ettensohn et al., "Distribution of black shale in the Wufeng-Longmaxi Formations (OrdovicianSilurian), South China: major controlling factors and implications," Earth Science, vol. 32, no. 6, pp. 819-827, 2007.

[19] C. Chen, D. Hu, D. Westacott, and D. Loveless, "Nanometerscale characterization of microscopic pores in shale kerogen by image analysis and pore-scale modeling," Geochemistry, Geophysics, Geosystems, vol. 14, no. 10, pp. 4066-4075, 2013.

[20] I. Y. Akkutlu and E. Fathi, "Multiscale gas transport in shales with local kerogen heterogeneities," SPE Journal, vol. 17, no. 4, pp. 1002-1011, 2012.

[21] M. E. Curtis, B. J. Cardott, C. H. Sondergeld, and C. S. Rai, "Development of organic porosity in the Woodford shale with increasing thermal maturity," International Journal of Coal Geology, vol. 103, pp. 26-31, 2012.

[22] S. Emmanuel, M. Eliyahu, R. J. Day-Stirrat, R. Hofmann, and C. I. Macaulay, "Impact of thermal maturation on nano-scale elastic properties of organic matter in shales," Marine and Petroleum Geology, vol. 70, pp. 175-184, 2016.

[23] H. Zhu, Y. Ju, Y. Qi, C. Huang, and L. Zhang, "Impact of tectonism on pore type and pore structure evolution in organic rich shale: Implications for gas storage and migration pathways in naturally deformed rocks," Fuel, vol. 228, pp. 272-289, 2018.

[24] E. Fathi and I. Y. Akkutlu, "Matrix heterogeneity effects on gas transport and adsorption in coalbed and shale gas reservoirs," Transport in Porous Media, vol. 80, no. 2, pp. 281-304, 2009.

[25] H. Zhu, A. Jia, and Y. Wei, "Characteristics of microscopic pore structure and methane adsorption capacity of shale in the Longmaxi Formation in the Zhaotong area," Petroleum Geology and Recovery Efficiency, vol. 25, no. 4, pp. 1-6, 2018.

[26] X. Tang, Z. Jiang, S. Jiang, and Z. Li, "Heterogeneous nanoporosity of the Silurian Longmaxi Formation shale gas reservoir in the Sichuan Basin using the QEMSCAN, FIB-SEM, and nanoCT methods," Marine and Petroleum Geology, vol. 78, pp. 99109, 2016.

[27] Y. Shu, Y. Lu, L. Chen, C. Wang, and B. Zhang, "Factors influencing shale gas accumulation in the lower Silurian Longmaxi formation between the north and South Jiaoshiba area, Southeast Sichuan Basin, China," Marine and Petroleum Geology, vol. 111, pp. 905-917, 2020.

[28] F. X. Huang, H. D. Chen, M. C. Hou, Y. J. Zhong, and J. Li, "Filling process and evolutionary model of sedimentary sequence of Middle-Upper Yangtze craton in Caledonian (Cambrian-Silurian)," Acta Petrologica Sinica, vol. 27, no. 8, pp. 2299-2317, 2011.

[29] X. Liang, G. Wang, Z. Xu et al., "Comprehensive evaluation technology for shale gas sweet spots in the complex marine mountains, South China: a case study from Zhaotong national 
shale gas demonstration zone," Natural Gas Industry B, vol. 3, no. 1, pp. 27-36, 2016.

[30] Z. X. Jiang, L. Guo, and C. Liang, "Lithofacies and sedimentary characteristics of the Silurian Longmaxi Shale in southeastern Sichuan Basin, China," Journal of Palaeogeography, vol. 2, no. 3, pp. 238-251, 2013.

[31] H. R. Zheng, B. Gao, Y. M. Peng, H. K. Nie, and F. R. Yang, "Sedimentary evolution and shale gas exploration direction of the lower Silurian in Middle-Upper Yangze area," Journal of Palaeogeography, vol. 15, no. 5, pp. 645-656, 2013.

[32] R. G. Loucks, R. M. Reed, S. C. Ruppel, and D. M. Jarvie, "Morphology, genesis, and distribution of nanometer-scale pores in siliceous mudstones of the Mississippian Barnett shale," Journal of Sedimentary Research, vol. 79, no. 12, pp. 848-861, 2009.

[33] R. G. Loucks, R. M. Reed, S. C. Ruppel, and U. Hammes, "Spectrum of pore types and networks in mudrocks and a descriptive classification for matrix-related mudrock pores," AAPG Bulletin, vol. 96, no. 6, pp. 1071-1098, 2012.

[34] G. R. Chalmers, R. M. Bustin, and I. M. Power, "Characterization of gas shale pore systems by porosimetry, pycnometry, surface area, and field emission scanning electron microscopy/ transmission electron microscopy image analyses: examples from the Barnett, Woodford, Haynesville, Marcellus, and Doig units," AAPG Bulletin, vol. 96, no. 6, pp. 1099-1119, 2012.

[35] J. Klaver, G. Desbois, J. L. Urai, and R. Littke, "BIB-SEM study of the pore space morphology in early mature Posidonia Shale from the Hils area, Germany," International Journal of Coal Geology, vol. 103, pp. 12-25, 2012.

[36] J. B. Curtis, "Fractured shale-gas systems," AAPG Bulletin, vol. 86, no. 11, pp. 1921-1938, 2002.

[37] B. J. Cardott, C. R. Landis, and M. E. Curtis, "Post-oil solid bitumen network in the Woodford Shale, USA - a potential primary migration pathway," International Journal of Coal Geology, vol. 139, pp. 106-113, 2015.

[38] J. Chen and X. Xiao, "Evolution of nanoporosity in organicrich shales during thermal maturation," Fuel, vol. 129, pp. 173-181, 2014.

[39] C. R. Clarkson, B. Haghshenas, A. Ghanizadeh et al., "Nanopores to megafractures: current challenges and methods for shale gas reservoir and hydraulic fracture characterization," Journal of Natural Gas Science and Engineering, vol. 31, pp. 612-657, 2016.

[40] K. L. Milliken, M. Rudnicki, D. N. Awwiller, and T. Zhang, "Organic matter-hosted pore system, marcellus formation (devonian), Pennsylvania," AAPG Bulletin, vol. 97, no. 2, pp. 177-200, 2013.

[41] B. Ran, S. Liu, L. Jansa et al., "Reservoir characteristics and preservation conditions of Longmaxi shale in the upper Yangtze block, south China," Acta Geologica Sinica, vol. 90, no. 6, pp. 2182-2205, 2016.

[42] X. Wang, Z. Jiang, and S. Jiang, "Full-scale pore structure and fractal dimension of the Longmaxi Shale from the Southern Sichuan Basin: investigations using FE-SEM, gas adsorption and mercury intrusion porosimetry," Minerals, vol. 543, no. 9, pp. 1-26, 2019. 